\title{
Daily Chiaroscuro
}

\author{
Kathy Mezei
}

\section{Chiaroscuro quotidien}

Ce poème en prose intègre la poésie et le prosä̈que: l'imaginaire est entrecoupé par les irruptions du réel, perturbateur, riche en détails et émouvant. A l'incipit du poème, la narratrice entre dans un bois, allusion à celui de Dante et celui de Djuna Barnes. Dans le bois de 'l'imagination ténébreuse'. La narratrice se dit chasseuse urbaine; elle écoute le mugissement du monde. Autour d'elle, des histoires naissent et elle est attentive à ne pas se situer au centre de leur intrigue. Si insistant est le bruissement d'herbes, le bourdonnement des insectes. Avec son fils au bord de la mer, elle écrit la beauté mais également la violence qui se trouvent un peuau hasard et un peu partout. Elle prépare un conférence au sujet de L'étranger de Camus. Meursault. La violence du soleil. $P$ uis, c'est la nuit: elle fait le voyage d'un jour, paradoxalement foncé, à une nuit de rêves, $d^{\prime}$ amour, de sommeil et de déceptions. Il y a du temps pour écouter la nuit avant que le jour ne commence à parler.

Midway in the journey of our life

I found myself within a dark wood

Dante

Tout s'arrêtait ici entre la mer, le sable, et le soleil ...

L'étranger

Doctor, I have come to ask you to tell me everything you know about the night.

Nora, Nightwood

while walking in the morning, a robin swooped in front of me, dropped or let fall (something) to the road. On she flew to a branch, 


\section{Daily Chiaroscuro $\cdot 75$}

perched there, her beady eye flickering. I bent down: it was a baby chick, dead white and transparent, its green and orange organs visible [I have now been interrupted by a swarm of real estate agents appraising the house next door, the contractor come to fix the outsidebenches, the telephone ringing three times in a row]. The robin in the tree watched, I watched, and the humming of the world grew louder. I walked on into the dark wood where across my path lay a green slug, stretched full six inches, inert, slimy. I walked on under the shade of overhanging branches and in a patch of freshly strewn sand (strewn by whom?) was a single footprint. I walked onto the sunlit path, and in the sunshine shimmered brilliant butteryellow daisies and purpleclover. Reaching into the riot of colour, I plucked a bouquet, but the yellow and the purple faded in my hand and the green stems shrivelled. while walking.

II

From beyond Peru's desolate peaks El Nino blows hot across the Pacific [contractor again, laundry to be hung] And the Earth's migraine begins

III

[marking student papers]

In the night my daughter whispers, 'dark is maniac!'

IV

Reading Women's Review of Books, her name Helen Vedler evokes a Jamesian heroine, the novel serious, ruminating, circuitous, evolving around a crisis of morals or a meditation on the validity of art, the heroine wealthy, long-suffering, circuitously thoughtful no matter what

V

Speaking of reading, as a dog or cat marks new territory with its pee, a signature on trees or doors, I mark new places by opening my book on docks, balconies, living-rooms and hotel chambers; then I am at home.

VI

In the dark forest, alder falls into forked arms of alder below, creaking like a door opening slowly. Who will come in? [phone rings, cleaning 
lady comes, talks, bangs the vacuum cleaner around] If I do not find again the embracing alders, forest gothic romance, does it matter. Is the imprint on my imagination enough. Does the exact place, the virtual thing matter. In the dark imagination.

VII

He says emotions ripple over our small son's face like gusts across the sea.

VIII

carnage in the dark wood

shrew dead across the sunlit path

crushed coke tin

the skeletal robin chick gone

into the fragrance of hot cedar

[he calls needing a lost phone number]

intrudes patina of oil

scorch of sulphur

there fallen on the blackberry tangle

the chain saw massacre of alders

faded ketchup packet

no name chip package

alien in the village of mushrooms

dog shit

baking

stinking

in the sun

IX

[No prosepoem due to my daughter's fever and sore throat, rushing to the doctor, getting penicillin, and packing her off (joyfully, apprehensively) to camp anyway]

\section{$\mathrm{X}$}

'I'm a hunter,' says my neighbour, eyes watchful, heavy body, beer belly and all at the ready. I too am a hunter. An urban hunter. II gather the laundry on my way up to write this, delayed because of problems with the current issue of our journal]. Late at night / jogging listening for that fateful footfall. No sony walkmans for me - I listen to the 
humming of the world. Traffic, sirens, voices. I smell the offerings of the world. Exhaust, smoke, the surprise of roses. Stories unfold all round and I attentive lest the plot revert to me and I become the object of the story.

A nature hunter: Through the thick hot brambles I hurry my two children, hear the sudden crack of twigs, [more calls about the delay of the journal, my daughter's allergies, the diaperman cometh] sense, then see the large black shape rearing on the creek's other side. How loud the wren warbles in the listening silence. How insistent the whisper of grass, the murmur of insects. My children do not see theshapeas they sing along at the top of their voices my tuneless warning song.

\section{XI}

The soccer ball received the comment, 'it needs air,' by everyone who passed it by. Needing air it lay on the back patio, it lay in the front hall, it lay on the car floor. Sometimes someone would say, 'lets play soccer' or 'where is the soccer ball.' Still the soccer ball lay here or there, needing air.

\section{XII}

[No prosepoem since small son seemed to need mama today]

\section{XIII}

[lecture on The Stranger to prepare] Three. Three crows in huddle. At the seashore. Cawing, beaks ajar. Wings spread in acrimonious conference. Till one waddles away, clam in beak. Two remaining watch, beaks open in shrill complaint - o the sound of it - wings akimbo. [It was the sun Meursault said sunglare on the sea, sand, skin making me do it] One in half-hearted pursuit, head thrust forward. Broken by the sweet trill of sandpipers. Low tide in the sungreen seaweed.

\section{XIV}

How can it be that staring at the (straw) laundrybasket, Iam reminded of her face, a youngish woman at the seaside, part of a pack, fair hair in wings, eyes, nose, mouth configured in vacuous pout, desiring to be pert, in reality merely petulant. A laundrybasket on the patio empty of clothes. Next I will mistake my husband for a hat. 


\section{$\mathrm{XV}$}

As my hand compulsively curls and whorls (crushes) the straw grasses where I lie, I disturb a world beneath - ants, grasshoppers, scurrying things that hide in alarm.

\section{XVI}

As my son lifts a rock in the tidal pool, he watches the small crabs scurry from the shock of light. [voices call at the bottom of the stairs] I help him lower the rock, hear a crunch, gingerly raise it again. There a crab waving his remaining claw contemplates, puzzled, his amputated other in the sand.

XVII

[much depends on dinner and there is much to do]

\section{XVIII}

From the dark spaces of daylight walking we move into night. Here happens: Sleep. Love. Deception. Dark dreaming. At the hour of the wolf: Birth (my son) Death (my other son) (howling but who?) That moment before dark lightens. My children's eyes close. I close the door. Shut the machines off. There is time to listen to the night before day begins its speaking. 